
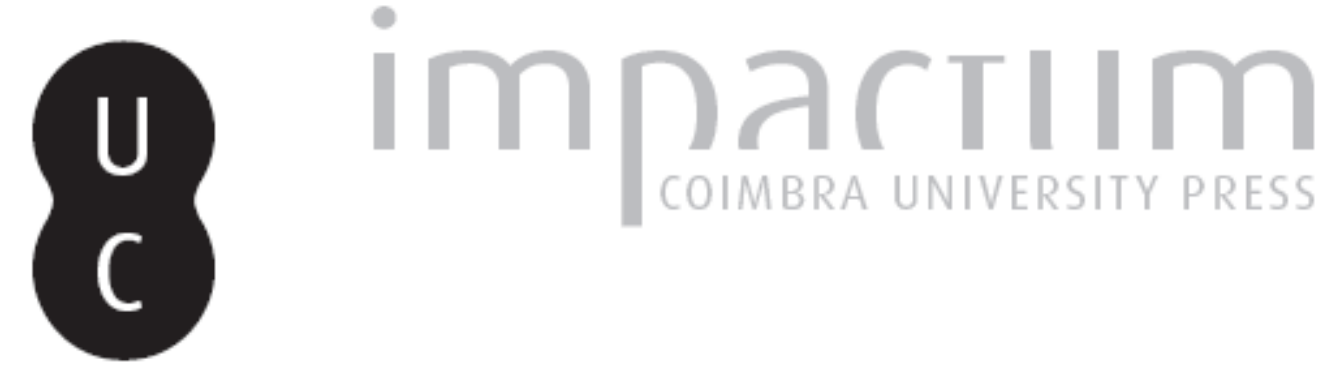

\title{
Os ministros da Ordem Terceira de S. Francisco de Coimbra no século XVIII: perfil social, famílias, redes de poder
}

Autor(es): $\quad$ Mota, Guilhermina

Publicado por: Imprensa da Universidade de Coimbra

URL persistente:

URI:http://hdl.handle.net/10316.2/37838

DOI:

DOI:http://dx.doi.org/10.14195/0870-4112_3-1_13

Accessed : $\quad$ 26-Apr-2023 08:14:33

A navegação consulta e descarregamento dos títulos inseridos nas Bibliotecas Digitais UC Digitalis, UC Pombalina e UC Impactum, pressupõem a aceitação plena e sem reservas dos Termos e Condições de Uso destas Bibliotecas Digitais, disponíveis em https://digitalis.uc.pt/pt-pt/termos.

Conforme exposto nos referidos Termos e Condições de Uso, o descarregamento de títulos de acesso restrito requer uma licença válida de autorização devendo o utilizador aceder ao(s) documento(s) a partir de um endereço de IP da instituição detentora da supramencionada licença.

Ao utilizador é apenas permitido o descarregamento para uso pessoal, pelo que o emprego do(s) título(s) descarregado(s) para outro fim, designadamente comercial, carece de autorização do respetivo autor ou editor da obra.

Na medida em que todas as obras da UC Digitalis se encontram protegidas pelo Código do Direito de Autor e Direitos Conexos e demais legislação aplicável, toda a cópia, parcial ou total, deste documento, nos casos em que é legalmente admitida, deverá conter ou fazer-se acompanhar por este aviso.

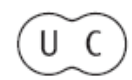




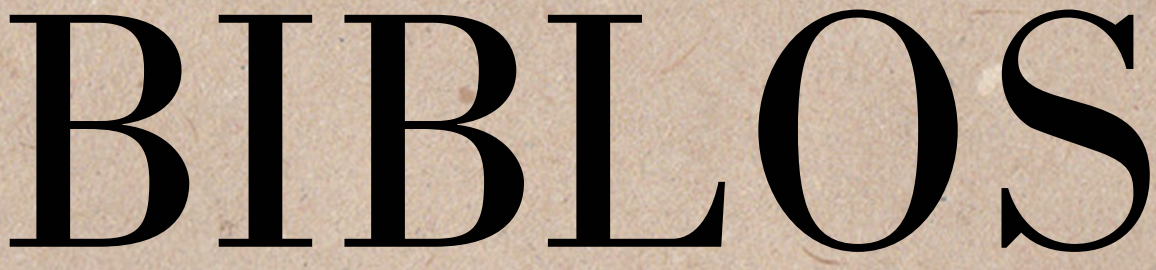

Revista da Faculdade de Letras da Universidade de Coimbra

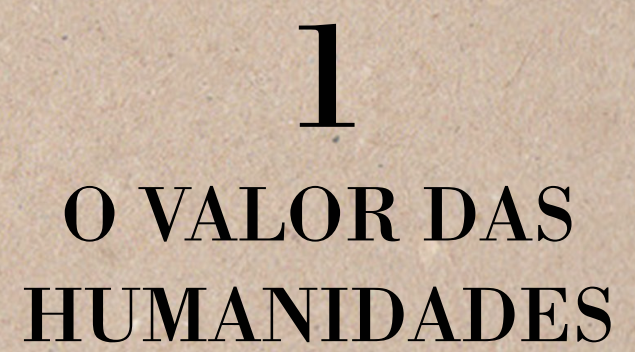

NÚMERO 1, 2015

3. ${ }^{a}$ SÉRIE 


\title{
OS MINISTROS \\ DA ORDEM TERCEIRA \\ DE S. FRANCISCO DE COIMBRA \\ NO SÉCULO XVIII: \\ PERFIL SOCIAL, FAMÍLIAS, \\ REDES DE PODER
}

The Ministers of the Third Order

of St. Francis of Coimbra in the eighteenth

century: social profile, families

and networks of the powerful

\author{
GUILHERMINA MOTA \\ guimota@mail.telepac.pt
}

Faculdade de Letras da Universidade de Coimbra

DOI

http://dx.doi.org/10.14195/0870-4112_3-1_13

Recebido em setembro de 2014

Aprovado em janeiro de 2015

Biblos. Número 1, $2015 \cdot 3 .^{\text {a }}$ série

pp. 311-343 


\title{
GUILHERMINA MOTA
}

\section{RESUMO.}

Este trabalho constitui uma primeira abordagem ao estudo dos ministros da Ordem Terceira de S. Francisco de Coimbra que exerceram o seu mandato no século xviII.

A caraterização social dos que governaram a Ordem nesse período mostra que esta instituição tinha pendor elitista, mas também capacidade para atrair a gente mais ilustre da cidade para os seus cargos diretivos. Foram ministros fidalgos de primeiro plano, lentes da Universidade, dignidades e cónegos do Cabido, priores de Igrejas Colegiadas, juristas e cidadãos da governança camarária, em alguns casos servindo durante vários anos.

Palavras-Chaves: Ordem Terceira de S. Francisco; Coimbra; Século xvini; Governo da Ordem; Elites dirigentes

\begin{abstract}
.
This paper is a preliminary approach to the study of those Ministers of the Third Order of St. Francis who discharged their mandate in eighteenth-century Coimbra. A sociological profile of the rulers of the Order during this period shows that the institution had an elitist bias, but also that its executive positions were able to attract the city's most distinguished people. Ministers were gentlemen, aristocrats, University professors, dignitaries and canons of the cathedral chapter, rectors of collegiate churches, jurists, citizens and aldermen (some with many years of service).
\end{abstract}

Keywords: Third Order of St. Francis; Coimbra; 18th Century; Governance of the Order; Ruling elites 
A Venerável Ordem Terceira da Penitência de S. Francisco de Coimbra ${ }^{1}$, fraternidade fundada em 1659 - fundação que se inscreve num momento de revitalização da Ordem Terceira muito estimulada pela reforma tridentina integrava-se pela sua orgânica e desígnio nas Ordens Terceiras Franciscanas. Criadas no século xıII, estas associaçôes leigas, mas vinculadas a uma ordem religiosa, congregavam homens e mulheres que procuravam o aperfeiçoamento moral, a redenção através da penitência, o incremento do culto e da doutrina cristâs, o louvor da caridade e da piedade, testemunhando na sua vida quotidiana o ideal franciscano (Araújo 2001; Araújo 2004; Moraes 2010b).

Para além das funçóes devocionais a que se obrigavam, que constituíam a sua principal missão, os terceiros desempenharam também em Portugal, a partir de meados do século XVIII, um papel valioso no domínio da assistência, apoio aos necessitados, amparo na morte, socorro hospitalar (Eiras 1980; Sá 2000; Silva 2014). Tiveram também uma ação de relevo em terras ultramarinas, designadamente na ocupaçâo do território brasileiro e no desenvolvimento dos seus núcleos urbanos (Moraes 2010a). Atuaram ainda como promotoras da atividade artística, com as muitas construçóes realizadas em igrejas e capelas (Ferreira-Alves 2012a).

A exposição que se segue sobre os dirigentes da Ordem Terceira coimbrã na centúria de setecentos é somente uma primeira abordagem ${ }^{2}$, porque náo é conhecida a arquitetura e a força económica da instituição, o poder efetivo que decorria do seu governo e a posiçáo específica que proporcionava no contexto das relaçóes sociais. O que parece comprovada, contudo, é a atraçáo que a Ordem exercia sobre a gente mais ilustre da cidade.

Uma das qualidades que se requeriam a quem desejava entrar na Ordem Terceira de S. Francisco, como irmão, era a da chamada "limpeza de sangue".

\footnotetext{
Sobre esta instituição, ver Barrico 1895.

2 Este trabalho foi desenvolvido a partir da lista dos ministros publicada por Ana Margarida Dias da Silva (Silva 2013: 14-19). Levou também em conta algumas alteraçóes a esse documento comunicadas pessoalmente pela Autora, a quem muito agradeço. Para traçar o perfil social dos ministros, foi imprescindível a consulta das seguintes obras: Fonseca 1995b, Soares 2001, Soares 2002, Lopes 2002/2003, Rodrigues 1992, Rodrigues 2003.
} 
O candidato náo podia pois descender de judeu, mouro ou negro ou, como se dizia, de qualquer infecta nação. Como se sabe, era esta uma imposição generalizada no acesso a diferentes instituiçóes e cargos. Esta cláusula, no entanto, desapareceu dos estatutos ainda no século xviır. Exigia-se também que fosse católico, de bons e louváveis costumes, sem mácula de crime ou infâmia, e que possuísse bens suficientes para a sua manutenção, ou que exercesse uma profissão digna que honrasse a Ordem. Foi recusada a entrada, por exemplo, a um pasteleiro e a uma vendeira da praça (Silva 2013: 39), pois tinham profissóes consideradas vis e não honradas.

$\mathrm{Na}$ escolha dos governantes, o crivo seria ainda mais apertado. E, na verdade, os ministros da Ordem Terceira estudados eram de cepa cristã-velha ou, então, já libertos do ferrete de um nascimento adverso. Por outro lado, metade dos ministros leigos eram cavaleiros professos da Ordem de Cristo, quase um terço alcançou a familiatura do Santo Ofício e um quarto dos ministros clérigos eram deputados deste Tribunal. Vemos assim que o recrutamento dos homens que governaram a Ordem Terceira em Coimbra se procurou fazer entre gente que correspondia, do ponto de vista da condição e da qualidade, a critérios bem exigentes.

Aos ministros pertencia todo o governo temporal que geriam em conjunto com o definitório, os restantes membros da direção. A orientação espiritual competia a um comissário, religioso indicado pelo Convento de S. Francisco da Ponte, convento a que a Ordem estava vinculada. Aos ministros competia também examinar se os mesários e mais oficiais cumpriam com as suas respetivas obrigações. Pelos Estatutos confirmados em 1660, cuja redação parece reproduzir a dos Estatutos Gerais da Ordem Terceira em Portugal, a mesa definitorial, corpo que representava a cabeça de toda a Ordem e na qual repousava todo o poder e autoridade, constava de um ministro, um secretário, seis ou oito definidores, um síndico, um vigário do culto divino, zeladores, sacristães e um vice-visitador; entre as irmãs, uma ministra e zeladoras ${ }^{3}$. Em Estatutos redigidos depois, passou a sua composição a ter dezoito irmãos professos: mi-

\footnotetext{
3 A. V. O. T. Livro dos Estatutos ..., cap. 5. ${ }^{\circ}$, fl. 3.
} 
nistro, vice-ministro, mestre de noviços, secretário, procurador-geral, síndico, cinco definidores eclesiásticos e outros tantos seculares, e dois vigários do culto divino ${ }^{4}$. As decisôes sobre a vida da corporação eram tomadas em mesa e por maioria de votos. O ministro tinha, no entanto, autonomia em algumas matérias, como o despacho das patentes dos irmãos passageiros ou as petiçóes dos irmãos doentes pobres 5 .

A mesa definitorial era eleita anualmente ${ }^{6}$, sendo portanto o cargo de ministro, como seu primeiro oficial, igualmente anual. Esse facto não invalidava que um ministro pudesse voltar à direção da Ordem em anos posteriores, não havendo limitação do número de mandatos. Verifica-se o acatamento dessa disposição nas duas primeiras décadas de setecentos. A partir de então, a ocupação do cargo foi mais estável, pois nos primeiros 20 anos houve 16 ministros diferentes e nos últimos 80 houve apenas 25 , chegando os ministros a permanecer nove, dez e até catorze anos seguidos no cargo. A esta maior disponibilidade para servir a Ordem, não deve ser alheia a crescente prosperidade dos irmáos terceiros, se bem que nos anos oitenta tivesse atravessado momentos de alguma turbulência, como se verá mais adiante.

A nobreza coimbrã teve no século XVIII uma forte representação na direção da Ordem, desempenhando o cargo de ministro em 39 anos. Por ele passaram as famílias mais prestigiadas, de orgulhosa linhagem antiga, da mais conservadora fidalguia, gente da governança da terra, com presença nas vereações camarárias e que tinha assento nas diversas sedes de poder da cidade.

No topo da fidalguia antiga estava a família Sá Pereira, detentora de extensos bens fundiários e de uma grande fortuna. O fidalgo cavaleiro Joáo de Sá Pereira [1661-1750], filho de Manuel de Sá Pereira e de D. Luísa de Melo (dos fidalgos da Várzea), era senhor dos morgados do Sobreiro e de Condeixa,

4 Esta composição consta de Estatutos não datados, mas redigidos no século XVIII (A. V. O. T. Estatutos da Ordem, cap. 5. "Definitorio", arts. 1. ${ }^{\circ}$ e 2.0).

5 A. V. O. T. Estatutos da Ordem, cap. 7.0 "Do Irmāo Ministro", art. 3. .

6 Até 1723 , a eleiçấo decorria no final de cada ano, ou no princípio do seguinte, sendo publicado o seu resultado em dia de Reis. Depois, por deliberaçâo tomada em capítulo de 19 de dezembro desse ano, a eleiçấo passou a ser feita na segunda oitava do Espírito Santo (Barrico 1895: 16). 
cavaleiro da Ordem de Cristo com comenda e tença. Exerceu na cidade todos os cargos: os de espada, pois foi capitão-mor de Coimbra e mestre de campo dos auxiliares, no município, onde foi vereador, seguindo tradição familiar, na justiça, como ouvidor da comarca, na administração, sendo provedor-mor da saúde; foi ainda comendador da redízima do sal da alfândega de Setúbal, provedor da Misericórdia de Coimbra em diversos anos e provedor do Hospital de S. Lázaro, ofício de que a família tinha a propriedade. Foi ministro da Ordem por cinco vezes (em 1702, 1711, 1717, 1724 e 1725). Era pessoa com tanto poder e influência que até conseguiu autorização régia para fechar um caminho público, que ia de Condeixa-a-Nova para Eira Pedrinha, e atravessava uma sua propriedade, desviando-o para outro trajeto (Soares 2001: 279).

O filho deste, e de sua prima D. Joana de Sá Pereira, Manuel de Sá Pereira [1690-1764], com mandato terceiro em 1723, herdou a casa e condiçáo de seu pai, com os mesmos títulos, preenchendo os mesmos lugares, e acrescentando ainda o de familiar do Santo Ofício. Foi também escrivão e provedor da Misericórdia em vários anos e, em 1759, mordomo da Universidade em Treixede. Foi acionista, em 1764, da Companhia Geral da Agricultura das Vinhas do Alto Douro, com direito a voto (Macedo 1951: 272). Era o homem mais rico da cidade com renda anual calculada em 1727 em 15 mil cruzados (Soares 2002: 83). Quer o pai, quer o filho, assistiam a maior parte do ano em Condeixa-a-Nova, no seu solar, que foi destruído aquando das Invasóes Francesas (Soares 2001: 35), mas mantinham casa na cidade, situada na rua da Ilha, casa com seu quintal murado, pátio na entrada, cisterna no meio, varanda ao redor do pátio e janelas para "todos os ventos", exceto para leste ${ }^{7}$.

Também fidalgos de antiga linhagem eram os Melos, ao tempo da Restauração parentes muito próximos dos senhores da Casa de Povolide. Desta família foram ministros Duarte de Melo e Sousa, em 1709, e seu irmão António Luís de Melo e Sousa, em 1713. Este era senhor da quinta da Várzea, onde tinha capela particular junto às casas da quinta, e senhor de vários morgados e prazos,

Esta casa era prazo fateusim do Cabido (A. U. C. Cabido e Mitra ... Tombo das casas da cidade, de 1745, fls. 436v-438v). 
como o de Assafarge. Elemento da mais conservadora e poderosa fidalguia, foi capitão-mor da cidade e termo, com um domínio muito amplo, num momento de elitização do mando municipal por parte de uma oligarquia fidalga.

Família poderosa, que vinha dos inícios dos tempos modernos e cuja casa tivera "raro brilho em Seiscentos" (Soares 2002: 94), ainda aparentada aos Melos da quinta da Várzea, era a dos Leitôes de Sousa. Desta estirpe, foi ministro em 1729 João Francisco Leitão de Sousa, filho de António Leitão de Sousa e de D. Lourença Josefa Pereira Botelho. Fidalgo de primeira linha da governança camarária, bem próximo da tradicional nobreza de espada, um dos homens mais ricos da cidade, possuindo por essa altura quatro a cinco mil cruzados de rendimento por ano. Morava à porta da Traição, mas tinha quintas em Banhos Secos e em Ribeira de Coselhas. Aceita ser ministro na Ordem num momento em que se recusa a integrar as vereaçóes camarárias (quando a primeira fidalguia da cidade saiu em bloco do poder concelhio), invocando a circunstância de viver a maior parte do ano com um tio fora da cidade (Soares 2002: 81-82).

Oriundos de fora de Coimbra, pois têm origem na vila de Montemor-o-Velho, mas há muito insertos nos círculos de poder da urbe coimbră, eram os Sás Pessoas, com casa na rua das Fangas e quinta em Santa Clara, a das Canas, família que se posicionava entre as mais abastadas. Entre 1753 e 1755, foi ministro o cónego António Pessoa de Sá Figueiredo e Cunha, elemento desta família, filho de Bernardo de Sá Pessoa. Este último era fidalgo da Casa Real, e foi capitáo-mor da vila de Pombeiro, vereador da Câmara conimbricense, deputado dos Marachóes do Mondego, provedor e escrivão da Misericórdia.

Logo a seguir, em 1756, está no governo da Ordem António Xavier Zuzarte Maldonado Cardoso [1707-1777], filho de Francisco Zuzarte Maldonado e de D. Mariana Machado ${ }^{8}$. Era assistente do correio-mor em Coimbra, ofício que herdara, e morava na mesma rua das Fangas, na sua casa, que tinha brasáo

\footnotetext{
8 Sobre as famílias Zuzarte e Brito e Castro, e sobre Filipe Sampaio e Melo, ver Ribeiro 2012: I: $169-175,217-234$ e $307-334$ e II: 106-113 e 203-240.
} 
de armas ${ }^{9}$. Foi vereador (a família tinha assento nas vereações desde o século anterior), superintendente das coudelarias da comarca, capitão-mor de Eiras, tendo ocupado a provedoria e a escrivania da Santa Casa em vários anos. Em 1735 , o rei concedeu-lhe a propriedade do ofício de escrivão do Hospital Real de Coimbra, que fora já do pai, e em 1765 a Universidade nomeou-o mordomo no Taveiro. Fidalgo de fresca data (o pai obtivera o alvará de fidalgo cavaleiro em 1717), era cavaleiro professo da Ordem de Cristo, senhor de um notável conjunto de bens de morgadio e de bens livres, localizados sobretudo na zona de Eiras. Em 1764, entrou para o projeto estatal da Companhia Geral da Agricultura das Vinhas do Alto Douro, com direito a voto (Macedo 1951: 268), tendo-lhe a Misericórdia concedido um empréstimo de três mil cruzados para a compra das açóes (Elias 2010: 265-266). Em 1777, quando se candidatou ao cargo de superintendente das coudelarias da comarca, que vagara por morte do pai, foi calculada em dez mil cruzados a renda do seu filho Francisco Zuzarte de Quadros e Meneses. Veja-se, por exemplo, que Luís Pedro Homem de Figueiredo Deus Dará, fidalgo da Casa Real, na época senhor da quinta das Lágrimas, que concorreu ao mesmo cargo, teria apenas metade disso ${ }^{10}$.

Casa também destacada e com poder na cidade, e ligada por parentesco com a anterior, era a da família Brito e Castro. Originária da região de Oliveira do Hospital, detinha um importante património, com diversas casas, vínculos e propriedades, quer na cidade e seus aros, quer nas terras de origem e outros lugares da Beira. Em Coimbra, na quinta da Portela, estava o seu solar, rodeado por olivais. A esta família pertencia o fidalgo da Casa Real António Xavier de Brito Barreto e Castro (filho de Manuel de Brito Barreto e Castro), ministro nos finais do século (1797-1799), deão da Sé de Coimbra, que encarnava a aposta que a família fizera no mundo do cabido catedralício, de pingues proventos ${ }^{11}$. Fora antes escrivão e, durante treze anos seguidos, provedor da Santa Casa.

\footnotetext{
9 Referência a esta casa (casa do "Correio") em Correia; Gonçalves 1947: 180 e em Soares 2001: 256-257.

${ }^{10}$ A. M. C. Eleiçōes Militares, t. III, 1771-1794, fls. 38v-39v.

${ }^{11}$ O lugar de deão renderia, nos inícios do século, três mil cruzados por ano (Fonseca 1995a: 133).
} 
Família vinda de Montemor-o-Velho é a de Filipe João Saraiva de Sampaio e Melo [1695-1782] que vai ser em Coimbra um homem poderoso. Filho de António Saraiva de Sampaio e Melo e de D. Filipa Luísa Coutinho, era fidalgo da Casa Real, cavaleiro professo da Ordem de Cristo, familiar do Santo Ofício; foi vereador da Câmara (com diversos mandatos), deputado dos Marachōes do Mondego, várias vezes escrivão e provedor da Misericórdia. Era senhor da quinta das Sete Fontes e dos morgados de Freches (Trancoso) e do de Vila Verde, que lhe veio por via da mulher, sua prima, D. Inês Luísa de Castro e Ayala. Para se avaliar da sua influência, basta dizer que, tendo a Coroa mandado, em 1749, afastá-lo da mesa da Santa Casa a que presidia, logrou voltar à provedoria por mais dois mandatos (Lopes 2002/2003: 215). Influente e rico: em 1764 atribuem-se-lhe oito mil cruzados de renda, montante de "nível plutocrata" (Soares 2002: 83). Geriu mal os bens familiares, pois, apesar de usufruir de táo grande fortuna, acumulou tantas dívidas que, em 1762, as obrigaçôes resultantes do capital e dos juros já perfaziam seis contos de réis. Viu-se assim obrigado a desfazer-se do prazo de Vila Verde para poder saldar o avultado débito à Misericórdia (Elias 2010: 282).

Também o seu comportamento não se revelou muito compaginável com os atributos que deviam ter os fidalgos da governança e os ministros da Ordem Terceira. Manteve uma relação duradoura com uma engomadeira sua vizinha (vivia ela na rua de Quebra-Costas e ele na de Sub-Ripas), relação de que nasceram dois filhos, batizados como filhos de pais incógnitos, um deles nascido ainda em vida da mulher ${ }^{12}$. Este menino era tido por seu filho, tratado como fidalgo, ensinado a andar a cavalo pelos criados de seu pai que também levavam todo o sustento necessário a casa de sua mãe. Toda esta conduta, assumida de forma pública, caiu mesmo sob a alçada punitiva da Visita Pastoral de $1763^{13}$.

${ }^{12}$ Este não era o primeiro caso pois, já casado e morador na sua quinta das Sete Fontes, tinha tido um filho ilegítimo de uma mulher solteira da vila de Eiras, batizado em agosto de 1735 .

13 Ela foi admoestada, ficou registada em primeiro lapso de concubinato e foi punida com multa de 400 réis; a culpa pertencente a ele, como cavaleiro, foi remetida para as justiças das Ordens Militares (A. U. C. Cabido e Mitra ... Visitaçôes. Livro da devassa das freguesias da cidade de Coimbra de 1763, fl. 54v). 
Filipe de Sampaio e Melo, após uma longa relação, anos depois de ter enviuvado $^{14}$, acabará por se casar em 1777 com esta mulher, Ana Vicência Joaquina, plebeia e humilde filha de um sapateiro que, ironicamente, virá a ser a matriz do futuro tronco de varonia da família, pois os filhos legítimos masculinos que o fidalgo havia tido de sua prima haviam morrido entretanto. Este fidalgo foi ministro da Ordem Terceira entre 1778 e 1782, já bastante idoso. Para o primeiro mandato foi eleito pelos membros da mesa da Ordem Terceira, para o de 1779 por mesa feita pelo padre provincial — investida na posse dos cargos pelo corregedor, em cumprimento de ordem régia (Barrico 1895: 32-33) —, mantendo-se da mesma forma no lugar nos anos seguintes.

Com efeito, durante o seu mandato, em junho de 1778, estalou um conflito entre a Ordem e os frades de S. Francisco da Ponte, tomando ele o partido dos religiosos. O comissário, Fr. José de Jesus Maria, indo contra o que estava em uso, avocou a si o direito de propor, para votaçáo, a lista dos irmáos a integrar a Mesa diretiva para o ano seguinte, direito que pertencia ao definitório terceiro. Essa decisão desencadeou uma guerra aberta, seguindo-se um período muito conturbado. A Ordem veio a retomar os seus privilégios em 1789, por deliberação do papa Pio VI, mas só em 1816 a concórdia foi completamente restabelecida, voltando os religiosos da Ponte a exercer o cargo de comissário e regressando os irmáos à capela contígua ao convento (Barrico 1895: 29-64).

Esta contenda de Coimbra não foi um fenómeno isolado - questão semelhante surgiu em Braga (Moraes 2010b: 44-45 e 550) — pois, na centúria de setecentos, os religiosos franciscanos intentaram amiudadas vezes apertar o controlo sobre as associaçóes dos irmãos terceiros, que conheciam um momento de expansão e de crescimento económico, e estes resistiram e lutaram por uma maior liberdade de ação.

Fidalgos com um pé em todos os lugares relevantes da cidade são os Correias de Lacerda. Família com raízes na cidade de Lamego e na zona de Viseu, mas que há geraçôes tinha a propriedade do ofício de secretário e de mestre de cerimónias da Universidade de Coimbra. Foi ministro Bernardo

\footnotetext{
${ }^{14}$ A primeira mulher faleceu em 10 de novembro de 1756 (A. U. C. Livro de óbitos. Coimbra, Sé).
} 
Correia de Lacerda (filho de João Correia da Silva), cavaleiro da Ordem de Cristo, que desempenhou o cargo três vezes (em 1703, 1710 e 1716). Pertenceu à vereação coimbrã, foi escrivão e provedor da Santa Casa. Era o senhor da muito conhecida quinta das Lágrimas, que constava de casas, terras lavradias, vinhas, olivais, árvores de fruto e sem fruto, azenha de moer pão, lagares de vinho e de azeite. O domínio útil desta quinta será vendido em 1730, pelo seu filho Pedro Correia de Lacerda, na sequência de um processo de esponsais muito complicado que o opôs a um outro ministro da Ordem de que falarei mais à frente, Manuel Mendes de Sousa Trovão, tendo a família Correia de Lacerda abandonado a cidade (Mota 2013: 385).

De fidalguia mais recente, alcandorado a partir do oficialato camarário, é Francisco de Morais e Brito da Serra, filho do mestre de campo Francisco Garcês de Brito. Natural da vila da Azambuja, singrou na cidade coimbrã ao aliar-se por casamento ${ }^{15}$ aos Morais da Serra, família em posse da escrivania da Câmara desde o século XVII. Foi escrivão da Câmara (entre 1724 e 1747) e deputado dos Marachôes, vereador em diversos anos, provedor da Misericórdia, instituição a que pediu vultuosos empréstimos (Elias 2010: 265-267). Um deles, de três mil cruzados, contraído em 1757, destinou-se à compra de açóes da Companhia estatal das Vinhas do Alto Douro, já referida, para a qual entrou em 1764 com direito a voto (Macedo 1951: 269). Grande toureiro na vila do Cartaxo, acabou com uma dinastia de escrivães da Câmara — que chegara a ser tão faustosa que Francisco de Morais da Serra, seu sogro, se servia com carrocim de quatro rodas - pois teve de vender em 1747 o ofício ao mercador florentino Fernando Maria Martini (homem de negócio "grosso", que manejava milhares de cruzados), e fê-lo por estar cheio de dívidas e não ter outros meios para satisfazer os credores, uma vez que todos os seus bens, salvo o ofício de escrivão, eram património vinculado (Soares 2002: 79-80 e 104). Foi ministro durante cinco anos, de 1757 a 1761.

${ }^{15}$ Casou-se em 17 de maio de 1715 com D. Leonor Angélica Morais de Lara e Sousa, filha de Francisco de Morais da Serra e de D. Maria de Vasconcelos (A. U. C., Livro de casamentos. Coimbra, São Bartolomeu). 
Gente da governança concelhia que vinha do século XVII é também a família Sá Romeu que tem, em 1718, António de Sá Romeu como ministro na Ordem.

Outras famílias fidalgas de primeira água, que costumavam andar nas vereanças e outros centros de mando, como a família Castelo Branco ou Macedo Velasques, não colocaram nenhum dos seus elementos masculinos na direção da Ordem, mas tiveram representação por mulheres da casa.

Ministra em 1728 foi D. Escolástica Josefa Margarida de Nápoles Castelo Branco. Era filha de Tomás de Sequeira Castelo Branco, vereador da Câmara e provedor dos Marachôes, escrivão da Misericórdia, fidalgo que pertencia ao núcleo mais elitista do poder autárquico. Esta senhora foi protagonista de uma história dramática, ao casar-se por amor, e com homem da sua escolha, o licenciado Manuel de Freitas Aranha. Mulher ilustrada e dona de uma vontade forte, ousou afrontar a prepotência de seu pai, homem de feitio irascível, conseguindo licença para o seu matrimónio na Câmara Eclesiástica, o qual se realizou na igreja de S. Pedro em maio de 1709 (Mota 2009: 116-117).

Da família Macedo Velasques, da quinta da Copeira, foram ministras duas mulheres: em 1775, D. Leonor Josefa Gertrudes da Gama e Brito, natural da vila de Olivença e moradora na rua de Quebra-Costas, viúva de Marçal de Macedo Velasques Sá e Oliveira. Este era filho de Jorge de Macedo Velasques, fidalgo, cavaleiro da Ordem de Cristo, que fora vereador, e irmão de António de Macedo Velasques Sá e Oliveira, capitão-mor de Coimbra em 1729. Dois anos depois, em 1777, foi ministra D. Joaquina Maria Xavier Libânia de Macedo Velasques Brito e Oliveira, filha da anterior, casada com Carlos Cordes Brandão Almeida e Ataíde, fidalgo da Casa Real, natural da vila do Sardoal ${ }^{16}$.

\footnotetext{
${ }_{16}$ Também outras ministras foram familiares de fidalgos que dirigiram a Ordem: D. Mariana Plácida de Meneses, casada com Manuel de Sá Pereira; sua filha, D. Mariana Antónia de Sá e Meneses; D. Isabel Maria Pereira de Meneses Souto Maior, mulher de António Luís de Melo e Sousa; D. Lourença Josefa Pereira Botelho, mãe de João Francisco Leitão de Sousa; Isabel Maria Pessoa de Sá Figueiredo e Cunha, irmã do cónego António Pessoa de Sá Figueiredo e Cunha; D. Brites Madalena de Quadros e Meneses, mulher de António Xavier Zuzarte Maldonado Cardoso. Informaçōes tiradas de um estudo que tenho em curso sobre as mulheres ministras.
} 
Não abordando agora a questão da participação das mulheres — matéria em que os Terceiros, ao admitir o seu ingresso na Ordem, têm uma atitude bem diferente da da Misericórdia que o excluía —, não deixo de frisar que a simples existência do lugar de ministra, nas ordens terceiras, é muito singular para a época, o qual, pelos Estatutos, ficava ao critério do padre comissário e do irmão ministro ${ }^{17}$. O cargo não deveria prever a possibilidade de ter voz nas deliberaçóes tomadas, nem a presença em reunióes de mesa, e a intervenção das ministras cingia-se certamente ao setor feminino. Apesar disso, a instituição, à imagem de outras suas congéneres ${ }^{18}$, ofereceu às irmãs um papel próprio, numa área de atuação que era eminentemente masculina.

Todas estas famílias procuravam o enriquecimento patrimonial e o reforço de prestígio numa "sociedade de honra". As estratégias matrimoniais (com alianças dentro do seu próprio grupo, por vezes com casamentos consanguíneos, ou com senhoras que traziam dotes e rendimentos avultados), a instituiçáo de morgadios para evitar a fragmentaçáo dos bens, o usufruto de rendas, a posse do hábito de uma ordem militar, como a de Cristo, ou de um lugar de familiar do Santo Ofício, eram cruciais para conseguir esse engrandecimento. Mas este consolidava-se também com o desempenho de cargos nas estruturas administrativas. Estes cargos, para além dos emolumentos que traziam, traziam também, o que era fundamental, poder para tomar decisóes que envolviam largos espaços e muita gente, a gestão de somas por vezes avultadas, a criação de clientelas e compadrios em redes de favor.

Pelo elevado número de ministros saídos das fileiras da fidalguia se deduz que era esta uma instituição que corresponderia aos interesses destas famílias,

17 «Antre as Irmáas se custuma auer Ministra e Zelladoras; que em algumas partes convem que as haja e em outras não; isto se deixa à vontade do P.e Comissario e do Irmão Ministro» (A. V. O. T. Livro dos Estatutos ..., cap. 5. ․, fl. 3). A forma como está redigido este capítulo indicia que estes Estatutos reproduzem os Estatutos Gerais da Ordem Terceira em Portugal.

${ }^{18} \mathrm{O}$ cargo de ministra existia na Ordem Terceira de Braga - embora a presença das ministras nas reuniōes da mesa, ou a sua assinatura em documentos, não esteja registada (Moraes 2010b: 85) — , mas não na de Vila Viçosa, não constando dos seus Estatutos (Araújo 2004). Em Braga, as ministras tinham "sob sua responsabilidade o financiamento da festa de Santa Isabel, Rainha da Hungria, pagando missa, música e sermáo” (Moraes 2010b: 103). 
tal como acontecia com a Misericórdia. Aliás, há um nítido jogo das cadeiras nos cargos de direção entre esta instituiçâo e a Ordem Terceira, pois uma boa parte dos ministros esteve também nos órgãos de direção da Santa Casa. Em princípio, seriam estas duas entidades rivais e concorrentes, como aliás o provou a questão dos funerais dos irmãos por meados do século. Nessa altura, a Ordem Terceira obteve alvará régio autorizando o uso de esquife próprio sem que a Misericórdia o pudesse impedir (Barrico 1895: 118-120) ${ }^{19}$, momento, segundo creio, em que as ordens terceiras passaram a receber a preferência dos particulares no que respeita aos enterros e os benefícios daí decorrentes (Sá 2000: 142). Rivalidade patente também em 1822, por ocasião do funeral do bispo D. Francisco de Lemos (Barrico 1895: 117-118), em mais um episódio da recorrente quezília das precedências ${ }^{20}$. $\mathrm{O}$ antagonismo existente entre estas corporaçóes inculca a ideia que a apetência pela sua chefia náo provinha de especial apego a nenhuma delas, mas sim do desejo ou da necessidade de um domínio que procurava nada deixar escapar.

A carreira académica surge, por sua vez, com um grande peso na seleção dos ministros, pois $26 \%$ são professores da Universidade, o que, no século XVIII, não acontecia na Misericórdia com os provedores (Lopes 2002/2003: 210 e 219). Como professores, e como membros da Escola, podiam ter também, e muitos tinham, interferência em outras esferas de açáo. Com efeito, alguns desempenharam ao mesmo tempo a função de cónegos doutorais ou magistrais, canonicatos estes que eram necessários ao serviço das dioceses, pois a eles competia fazer orientação teológica, dar pareceres e tratar de matéria jurídica, mas que eram também benefícios eclesiásticos que traziam compensaçóes de ordem financeira a quem os detinha. Por outro lado, a Universidade dispunha nessa época do direito de integrar as vereaçóes camarárias em Coimbra, a chamada enxertia doutoral21 ${ }^{21}$, e não são poucos os ministros que, sendo lentes,

\footnotetext{
19 O mesmo se passou em Vila Viçosa (Araújo 2004: 59-60).

${ }^{20}$ Idênticos atritos estalaram em Braga e em S. Paulo (Moraes 2010b: 552).

${ }^{21}$ Como diz Aires de Campos. Por privilégio atribuído pelo rei D. João III, a Universidade indicava um dos quatro vereadores da Câmara Municipal de Coimbra (Soares 1991: 45-80).
} 
passaram pela gestão municipal que, desde os inícios do século, suscitava um interesse crescente. E, claro, alguns deles, de Cânones ou Leis, desenvolveram também carreiras paralelas na administração central que exigia competência e perícia em Direito.

Estas valências reunia o Dr. António de Andrade Rego, fidalgo da Casa Real, lente de Cânones, representante de uma fidalguia letrada. Era filho do desembargador Inácio do Rego de Andrade, fidalgo da Casa de Sua Majestade, e de D. Madalena Maria de Lamirante. Foi ministro em 1727, ano da sua jubilação universitária. Apesar de seus ascendentes terem fama de cristãos-novos (a seu avô fora recusada a entrada na Ordem de Cristo), conseguiu ser colegial paulista. A aceitação por parte do Colégio Real de S. Paulo (de que foi mesmo reitor), onde a inquirição se costumava fazer com muito rigor, libertou-o dessa mancha (Marçal 2010: 113-114). Quando foi ministro, tinha sido já vereador da Universidade na Câmara coimbrã (1707-1708), desembargador da Relação do Porto (1714) e da Casa da Suplicação e titular dos Agravos (1716), cónego doutoral da Sé de Faro (1721). A este jurista estarão destinados depois mais altos voos vindo a ser em 1735 deputado e conselheiro da Mesa da Fazenda da Casa de Bragança (Marçal 2010: 134), a casa mais importante da Coroa. Foi também deputado da Inquisição de Lisboa, em 1751 (Machado 1965: 203-204 e Machado 1967: 23), já perto do fim da vida (morreu em 1755), e membro da Academia Real da História, nomeado para substituir o Padre Rafael Bluteau (Fonseca 1995b: 478).

Condiçóes que perfazia também o Dr. Manuel Nobre Pereira, ministro em 1728. Era lente de Cânones e colegial do Colégio Real de S. Pedro, onde entrou em 1706. Natural da zona de Alenquer, filho de Manuel Antunes e de Inês Nobre, gente que vivia dos rendimentos da terra, alcançou o lugar de cónego doutoral da Sé de Coimbra (1720) e foi também vigário capitular, lugar de altíssimo relevo, pois respondia pela diocese em momentos de sede vacante; foi ainda deputado da Inquisiçáo de Coimbra e vereador pela Universidade (1709-1710). Como acontecia com alguma frequência no meio académico (assim procedia também, por exemplo, o Dr. João da Costa Leitão), tinha ao seu serviço como pajens estudantes de poucos recursos.

Lente de Cânones era igualmente o Reverendo António Bernardo de Almeida, ministro entre 1762 e 1770, filho de Pascoal Marques de Almeida e de 
Francisca Maria Brandão. Natural da Baía, cidade onde havia rumor de sangue cristão-novo na família, fez o seu caminho sem sobressaltos. O problema da sua ascendência não o impediu de ser aceite no Colégio Real de S. Pedro (1730-1745) e de prosseguir a sua carreira, sendo cónego doutoral da Sé de Braga e chegando mesmo a ser deputado do Santo Ofício. Faleceu em agosto de 1770 e foi sepultado na igreja do Colégio de Santo António da Pedreira, templo de que foi insigne benfeitor, como se diz no seu registo de óbito ${ }^{22}$.

O Dr. Luís António Lopes Pires [1744-1808], natural desta cidade, filho de Bento da Conceição e de Teresa Rosa, foi ministro em 1785. Lente de Teologia, foi cónego doutoral da Sé de Viseu (1786) e da de Faro (1792) e cónego magistral da do Porto (1800) e da de Évora (1805). Exerceu as funçôes de secretário interino da sua Faculdade, jubilando-se em 1806.

Lente de Teologia era também o chantre da Sé de Coimbra, Dr. António da Cruz Ferreira, natural de Borba, filho de Manuel Rodrigues Guarda e de Joana Gomes de Seias, que foi ministro em 1730. Morava, em 1745, numa casa do Cabido, que possuía por aposentadoria vitalícia, situada ao arco de D. Jerónima, na rua que ia do Açougue para o Pilroteiro. Era uma boa casa de pedra, de dois sobrados, janelas de assentos, com uma dúzia de assoalhadas, cozinha, lojas, quintal com árvores de espinho e parreiras, estrebaria e palheiro; tinha oratório na sala chamada da Torre ${ }^{23}$. Com ele viviam suas irmás, provavelmente na sua dependência económica, pois a Universidade, após o seu falecimento, em março de 1760 , veio a conceder a essas senhoras uma tença de 25.000 réis a cada uma, por dizerem ter ficado no maior desamparo e já em idade avançada (Fonseca 1995b: 549-550).

Ministro nos seis anos seguintes foi o Dr. Manuel de Matos, que fora secretário da Ordem, lente de Leis, desembargador, cónego doutoral da Sé de Viseu, deputado do Santo Ofício.

Também lente de Leis e deputado do Santo Ofício era o Dr. João da Costa Leitão, nascido em 1683 em Oliveira do Conde, filho do juiz de fora João da

\footnotetext{
22 Faleceu em 14 de agosto de 1770 (A. U. C. Livro de óbitos. Coimbra, Almedina).

23 A. U. C. Cabido e Mitra ... Tombo das casas da cidade, 1745, fls. 78-81.
} 
Costa Leitão e de D. Ana Borges de Castro. Foi colegial de S. Pedro, desembargador titular da Relaçáo do Porto e da Casa da Suplicaçáo, vereador pela Universidade, cónego doutoral da Sé de Lamego. Na contestaçâo que lhe moveu o canonista que perdeu o provimento desta vaga de Lamego, o Dr. António Dinis de Araújo, foi apodado de "inhabil" (Fonseca 1995b: 541-542), mas a eventual falta de habilidade não lhe dificultou o salto para um alto cargo pois, em 1739, sendo já lente de Prima, despediu-se da Universidade para tomar posse como monsenhor da Patriarcal. Antes, havia sido ministro terceiro em 1726.

Pessoa com lugar de destaque na vida da Ordem é Francisco António Duarte da Fonseca Montanha Oliveira e Silva [1744-1825]. Lente de Leis, cavaleiro professo da Ordem de Cristo, era natural de Coimbra, filho do Dr. João Duarte da Fonseca, lente de Medicina, e de D. Maria Madalena da Costa Montanha e Silva ${ }^{24}$, e irmão do Padre José Montanha que foi missionário na China. Homem hábil e competente, desempenhou uma multiplicidade de cargos. $\mathrm{Na}$ Universidade, foi almotacé da Feira dos Estudantes (1765), vice-conservador (1778), vereador na Câmara pela Universidade (1783-1785), diretor da Faculdade de Leis (1803-1811), vice-reitor (1809-1813); na administraçấo central, foi desembargador dos Agravos da Casa da Suplicaçáo e desembargador do Paço; foi ainda cónego doutoral da Sé de Braga (1799) e da de Coimbra (1809), provedor da Misericórdia (1754-1756) e deputado da Inquisição de Coimbra. Teve carta de brasão de armas em 1788 (Ribeiro 2012: II, 84). Faleceu em setembro de 1825, deixando vários legados a instituiçóes de beneficência, a congregaçóes religiosas, como a de S. Francisco, uma soma apreciável à Ordem Terceira de

\footnotetext{
${ }^{24}$ Senhora por quem devia ter uma devoção especial, pois fez um requerimento pedindo que mais ninguém fosse inumado na cova da mãe, sepultada (em 5 de março de 1788) na igreja de Almedina, ao cimo do cruzeiro, junto ao altar da Senhora da Piedade. O pedido foi atendido, tendo sido colocada uma lápide com o nome e essa indicação em 3 de setembro de 1790 (A. U. C. Livro de óbitos. Coimbra, Almedina). Quando morreu, foi enterrado na mesma igreja, aos pés da sepultura da mãe, defronte do referido altar, em sepultura privada, mercê que lhe fora concedida em 1782 a requerimento seu (A. U. C. Cabido e Mitra ... Capelas, cx. VII, 9). Acresce que, durante o seu mandato de ministro (1784-1785), propôs, o que foi aceite, a eleição de Nossa Senhora da Maternidade como protetora da Ordem, para cuja festa deixou em testamento uma generosa quantia (Barrico 1995: 35-36).
} 
que era irmão, a casa em que morava, ao Marco da Feira, aos Hospitais da Universidade e a sua livraria a esta Escola.

Eleito em 1784 como ministro, não se conformou com as condiçóes de governo que então vigoravam, decorrentes da usurpação feita pelos religiosos franciscanos a que já aludi. Bateu-se com energia pela recuperação da autonomia e dignidade da Ordem, propôs a redação de novos estatutos e empenhou-se no restabelecimento da boa paz com os frades de S. Francisco da Ponte.

Da Universidade saiu assim muita gente disposta a assegurar a chefia da fraternidade terceira. Mas os ministros eram, de forma predominante, eclesiásticos. De facto, dos professores que dirigiram a Ordem, apenas dois eram leigos: o Dr. Lucas de Seabra e Silva [1694-1756] e o Dr. Francisco Lopes Teixeira [1714-1790].

O primeiro era natural de Lobão, concelho de Tondela, e era filho de Gregório de Seabra da Silva e de D. Antónia Ribeiro Pinto e casado com D. Josefa Teresa de Morais Ferraz. Era lente de Leis e foi colegial de S. Pedro, primeiro passo na senda do reconhecimento social. Este jurista, juntamente com a sua carreira académica, desenvolveu toda uma carreira na administração régia. Foi procurador da Universidade, juiz do Fisco em Coimbra, desembargador da Relação do Porto, conservador da nação inglesa na cidade de Coimbra, desembargador honorário da Casa da Suplicação e dos Agravos, conselheiro de Estado e da Real Fazenda. Atingido o topo da carreira universitária, como lente de Prima, saiu da Universidade para ir tomar posse de um lugar como desembargador do Paço em 1745. Foi ainda provedor da Misericórdia e do Hospital Real de Coimbra. Pessoa de valimento e consideração, virá a ser fidalgo da Casa Real, cavaleiro da Ordem de Cristo e senhor de vários morgados, como o de Lobão e Fail (em que sucedeu), o de Figueiró dos Vinhos (que lhe veio por casamento), e o de Vilela (que instituiu) (Lopes 2002/2003: 221). Foi ministro em 1752, transitando da provedoria da Misericórdia, cargo em que estivera nos dois anos anteriores (1749-1751).

O segundo era lente de Medicina (de Avicena) e o único que desta Faculdade esteve à testa da Ordem. Este professor, filho de Manuel da Costa Monteiro e de Maria do Ó, continuou um trajeto de ascensão já encetado pelo pai (um escrivão da correição que fora familiar do Santo Ofício), seguindo 
estratégias bem delineadas, que se viram coroadas de êxito. Vem a ser cavaleiro professo da Ordem de Cristo e a gozar de uma certa abastança. Foi irmão e médico dos dois partidos da Misericórdia (1749-1766) (Lopes 2000: I, 622-623) e médico dos cárceres secretos do Santo Ofício (1765); foi também vereador pela Universidade (1769-1772), daí passando para ministro da Ordem. Casou-se com 46 anos $^{25}$ já em posse de um conjunto assinalável de propriedades: a casa em que vivia na rua do Sargento-mor, mais duas no beco que dava para o Cais e uma na Calçada, uma quinta no Almegue (que valeria o melhor de dez mil cruzados) e um olival no sítio da Machada. A noiva, D. Bárbara Maria Antónia Xavier de Carvalho e Sousa ${ }^{26}$, filha de um lente de Avicena que também tinha a familiatura, trouxe mais em dote três casas e rendas consideráveis ${ }^{27}$. Em 1783, o Dr. Francisco Lopes Teixeira obteve licença para erigir uma capela junto à casa que possuía na sua quinta do Almegue ${ }^{28}$, o que evidencia as suas aspiraçóes ao estatuto da nobreza. Jubilou-se em 1772 e morreu em abril de 1790. Ficou sepultado na igreja do Colégio da Estrela e foi acompanhado por pobres até à sua última morada, como dispôs em testamento ${ }^{29}$.

A Universidade afirma-se cada vez mais, na Época Moderna, como um alfobre de elites e como um meio privilegiado de promoção pessoal. Tal acontece sobretudo com os juristas, mas também os médicos começam a romper com a menor estima social em que eram tidos e a habilitarem-se a lugares preponderantes. Se, para a fidalguia, estes lugares de governo na Ordem pouco acrescentariam ao seu estado, o mesmo se não dirá no que respeita aos saídos da academia. Para estes, o desempenho desses cargos fazia parte de um processo de ascensão social que se desenvolvia em simultâneo com outros. A nobilitação era muitas vezes o objetivo último destes lentes, para quem a formação académica fora a primeira etapa.

\footnotetext{
${ }^{25}$ No Seminário de Jesus Maria José, em 6 de março de 1760 (A. U. C. Livro de casamentos. Coimbra, S. Bartolomeu).

${ }^{26}$ Esta senhora foi ministra da Ordem em 1762-1764 e 1785.

27 A. U. C. Livros Notariais. Tabeliāo António Lopes da Cruz Freire, 1. 4, fls. 83v-84.

${ }^{28}$ A. U. C. Cabido e Mitra ... Capelas, cx. VII, 11.

29 A. U. C. Livro de óbitos. Coimbra, S. Cristóvão.
} 
Como vimos, alguns dos ministros clérigos em exercício no século XVIII eram professores da Universidade, mas uma boa parte pertencia ao Cabido da Sé de Coimbra ${ }^{30}$. Ao Cabido pertencia o deão António Xavier de Brito Barreto e Castro e o chantre Dr. António da Cruz Ferreira já mencionados. Mas pertencia também o arcediago Teotónio Valério de Figueiredo, que fora prior da freguesia de Pereira; natural do Taveiro, filho de um vereador e provedor dos Marachōes do rio Mondego, de igual nome, e de D. Catarina Eufrásia Luísa de Sousa, foi ministro cinco vezes (em 1771, 1772, 1774, 1775 e 1777). Um outro seu irmão, o cónego António José de Figueiredo e Sousa, pertencia também ao Cabido.

Cónegos e fidalgos são o já citado António Pessoa de Sá Figueiredo e Cunha, da família Sá Pessoa, e também o Ilustríssimo Joáo Vieira de Melo e Sampaio, fidalgo da Casa Real, filho de Domingos Vieira de Melo e de D. Catarina Joaquina de Sampaio, moradores que foram na sua quinta do Ribeiro, freguesia de S. Lourenço, bispado do Porto. Era cónego prebendado da Sé de Coimbra, morava na rua do Açougue, defronte da Sé, e foi ministro dez vezes (1782, 1783 e 1789-1796), falecendo em janeiro de 1805. E cónegos prebendados da Sé de Coimbra são também José de Melo, ministro em 1704, Domingos Monteiro de Albergaria, ministro em 1776, morador na rua da Ilha, e Francisco Xavier de Almeida Pais, ministro em 1800, morador na sua quinta de Ponte de Água de Maias na companhia de sua irmá, D. Caetana Pais de Almeida ${ }^{31}$.

Durante o mandato deste último, no mês de março de 1800, a Ordem Terceira organizou uma grandiosa procissáo de penitência, que foi da Sé Velha até à Igreja do Mosteiro de Santa Cruz, em que os irmãos se apresentaram sem capa, com coroa de espinhos na cabeça e na maior parte descalços. A procissáo tinha como intençáo implorar o auxílio divino para que cessassem as copiosas chuvas que caíam desde setembro e que haviam provocado grandes cheias no Mondego e prejuízos nos campos. Uma segunda procissão, de ação de graças, e com igual pompa, fez dias depois o caminho inverso (Barrico 1895: 86-90).

\footnotetext{
${ }^{30}$ Sobre os cabidos na Época Moderna, ver Almeida 1968: 57-69, Almeida 1970: $30-34$ e Silva 2011: 77-94.

${ }^{31}$ Faleceram ambos em 1801. A. U. C. Livro de óbitos. Coimbra, Santa Justa.
} 
E cónego é também o Dr. António Vigier, ministro em 1737. Pertencia a uma família originária do Languedoc francês que tinha a sua atividade no rico comércio das drogas, com um ramo instalado na capital. Em Coimbra, esta família teve aposta forte no clero, pois era mestre-escola da Sé o reverendo Francisco Vigier, irmão do cónego, terá o mesmo cargo depois o seu sobrinho José Vigier (escrivão da Misericórdia de 1759 a 1761), sendo outro seu sobrinho, António Vigier, beneficiado na Colegiada de Santa Justa. O Dr. António Vigier morava na rua das Covas, na casa a que chamavam a Casa dos Bicos, por ter umas pedras lavradas com os bicos para fora, que era do Cabido, e que também tinha por aposentadoria vitalícia: boa casa de dois sobrados, com dez compartimentos, uma chamada casa da Torre com quatro janelas de assentos, cozinha, alcovas, um pátio com sua varanda, cocheira, estrebaria, palheiro e armazém de azeite ${ }^{32}$.

Ministro durante uns longos 14 anos, de 1738 a 1751, foi o cónego Miguel de Souto Maior [1674-1752], filho de António Álvares e de Antónia Soares, que só não terá continuado por morte. Era natural de Lisboa, familiar da casa de D. António de Vasconcelos e Sousa, fidalgo que o apoiou na sua carreira e o nomeou cónego da Sé de Coimbra (cargo de que tomou posse em 1708), quando era bispo da diocese (Machado 1967: 257). Foi o cónego Souto Maior responsável por alguns melhoramentos feitos na catedral e era ele quem dirigia a mesa da Ordem Terceira quando, em 1740, se iniciou a construção da sua nova capela (para a qual contribuiu com $452 \$ 325$ réis) e teve a honra de lançar a primeira pedra. Por essa ocasiáo realizou-se uma solene procissáo por si presidida e em que os irmáos já referidos, o chantre António da Cruz Ferreira e o cónego António Vigier, juntamente com outro irmão terceiro e com o guardião de S. Francisco da Ponte, levaram aos ombros a charola com a primeira pedra. Este ministro estava ainda em exercício em 1743 quando, terminada a obra, celebrou missa pela primeira vez na nova capela (Barrico 1995: 20-28). Morava junto da Sé, mas já na rua da Ilha, numa casa do Cabido, que possuía sob o mesmo título do cónego anterior, e semelhante às outras já

32 A. U. C. Cabido e Mitra ... Tombo das casas da cidade, 1745, fls. 68-71. 
descritas, com dois sobrados, várias salas e quartos, cocheira, pátio com cisterna e quinchoso com flores ${ }^{33}$.

Por fim, foi ministro também, de 1720 a 1722, o meio cónego António Fernandes Velho. Fora cura proprietário da Sé em 1712 e será escrivão da Misericórdia anos depois (1729-1731). Era filho e irmão de reputados mercadores, sendo um dos irmãos o cidadão e familiar do Santo Ofício Manuel da Silva Caetano, mais tarde escrivão chanceler do fisco real da cidade. Fernandes Velho era clérigo cioso das suas prerrogativas, pois manteve uma pendência com o Cabido em 1716 por causa de benefícios a que se julgava com direito (Fonseca 1995a: 118). Possuía uma casa na rua da Calçada, de que fez a doação a Álvaro Antunes das Neves, lente de Medicina, e um prazo de casas e quintal na rua das Azeiteiras, que acabou por vender ao alcaide desta cidade, Félix da Rosa Brandão ${ }^{34}$. Vivia com desafogo económico, tendo ao seu serviço criados e escravos. Morreu em 1742 e foi sepultado na igreja de S. Francisco da Ponte ${ }^{35}$.

Mas nem todos os sacerdotes que foram ministros eram do Cabido. Podiam provir também de Colegiadas, como acontece com o prior da igreja de Santa Justa, o licenciado Mateus Vieira, ministro em 1705, ou com o rico e influente prior da igreja de Santiago, o Dr. Bento Antunes da Costa, escrivão da Misericórdia em 1690-1692 (Silva 1991: 61-62) e ministro em 1701. Este era filho de António Antunes, sirgueiro, que foi mester da mesa, homem que juntara uma soma de avultados cabedais. Uma filha sua, e irmã do prior, levara de dote mais de 10 mil cruzados ao casar-se com o Dr. João Pacheco Fabião, magistrado que fora juiz de fora em várias terras e provedor em Viseu. Um neto deste casal, Manuel Pacheco Fabiāo de Albuquerque e Melo, virá a entrar na fidalguia. O reverendo pároco náo desdenhava pôr o seu dinheiro a render a juro, como fez em 1700, quando emprestou 60 mil réis a um pintor da cidade ${ }^{36}$.

\footnotetext{
33 Ib., fls. 21-23v.

34 Idem, fls 343-346v e 350v-353v.

35 Faleceu em 13.1.1742 (A. U. C. Livro de óbitos. Coimbra, Sé).

36 A. U. C. Livros Notariais. Tabelião Pantaleão Cordeiro, 25 de março de 1700.
} 
O clero, no total, está altamente representado, pois mais de metade dos ministros são clérigos, o que coincide com o que acontece em outras Ordens Terceiras, como é o caso da de Braga. Nesta última, contrariamente ao que sucedia em Coimbra, havia uma modesta participação das famílias mais ilustres (Moraes 2010b: 135-138). De salientar também que o peso significativo do clero em Coimbra se deve muito ao facto de $40 \%$ dos eclesiásticos serem lentes da Universidade.

Atividade no foro tem o jurista Dr. Diogo Ribeiro Santiago, morador na quinta da Alegria, ministro em 1707, que tinha sido já secretário da Ordem em 1701. Era casado com D. Catarina Leonor de Almeida Carvalho que, nos anos quarenta do século, já viúva, terá uma casa sobradada na rua do Açougue ${ }^{37}$, prazo do Cabido, vizinha da do reverendo chantre António da Cruz Ferreira.

Igualmente advogado é o Dr. Bento Álvares, ministro de 1786 a 1788. Era casado com D. Comba Aires Correia e morava na rua de Sáo Cristóvão. Em 1774, é testamenteiro de Dionísio de Macedo Guimarães, que foi um importante e abonado mercador da cidade, cavaleiro professo da Ordem de Cristo e escrivão proprietário da Câmara coimbrã.

Jurista é também o ministro em 1715, o Dr. Manuel de Almeida, doutorado em Leis, e familiar do Santo Ofício, que fora desembargador da Mesa Eclesiástica da diocese de Coimbra, para onde transitou vindo da Santa Casa, onde fora escrivão de 1704 a 1706.

Com nobreza simples de cidadão, pertencentes ao mundo camarário, surgem três ministros. Têm percursos muito semelhantes, pois chegam ao poder concelhio em segunda geração, passando a afirmação social da família primeiro pela Universidade, uma vez que todos sáo filhos de lentes de Medicina.

Manuel do Vale Souto Maior, cavaleiro da Ordem de Cristo, homem da governança coimbrã, exerceu o cargo de ministro em 1712. O seu movimento ascendente passou pela Misericórdia, onde foi escrivão nos anos de 1699 (Silva 1991: 63-64) e 1702. À Santa Casa voltará depois, como escrivão entre 1715 e 1717 e como provedor em 1726. Era filho do Dr. Manuel Rodrigues do Vale, lente de Medicina e familiar do Santo Ofício, e de D. Maria Souto Maior. Seguiu os

${ }^{37}$ A. U. C. Cabido e Mitra ... Tombo das casas da cidade, 1745, fls. 180-183. 
passos do pai, pois este também fora vereador, se bem que da Universidade, e tinha estabelecido já a ligação da família com a Misericórdia, uma vez que tinha sido médico na instituição. No universo concelhio, Souto Maior iniciou-se, em 1701, como capitão de Ordenanças das freguesias de S. Pedro, Salvador e Almedina, cargo que deixou de lhe interessar, e do qual pediu escusa - a qual obteve por provisão do Conselho da Guerra — ${ }^{38}$, quando ambicionou o de vereador, de incomparável valoração social, que conseguiu atingir em 1704. Quando o município resolveu aumentar a casa da Câmara na Praça, através da compra de umas moradas na rua da Calçada, prontificou-se a emprestar 610 mil réis para esse efeito (Soares 2001: 265). Esta disposição e esta largueza mostram o apreço em que tinha a sua pertença à governança e também que gozava de um indubitável bem-estar económico.

Manuel de Abreu Bacelar [ca.1678-1732], licenciado em Medicina, foi ministro em 1714 (fora secretário da Ordem anos antes). Também era filho de um lente de Medicina, que também fora vereador pela Universidade, o Dr. António de Abreu Bacelar. Na sua rota de acrescento social conjugaram-se a Universidade, a Inquisição, o Município e o mundo dos negócios, pois foi vereador da Câmara, serviu de secretário da Universidade, foi mordomo da Universidade no Taveiro, médico e depois alcaide da Inquisição. Alcançou ainda o hábito de Cristo. Casou-se em 1708 com D. Teresa Josefa Ferreira, viúva de um lente de Medicina (o Dr. Manuel Moreira), mas que era filha de um conceituado impressor e livreiro, José Ferreira, cidadão que tomava rendas, o que lhe permitiu lançar a ponte para a vida camarária.

E por fim Manuel Mendes de Sousa Trovão, ministro em 1719, filho de um lente de prima de Medicina, de igual nome, que fora vereador pela Universidade. Era cavaleiro da Ordem de Cristo, serviu de secretário da Universidade e foi vereador da Câmara. Tinha bens herdados de seu pai e o seu casamento com D. Maria Micaela de Sousa, viúva do muito abonado mercador Domingos de Magalhães e Lima, consolidou ainda mais a sua posição económica. No entanto, vai enredar-se numa série de problemas, chegando mesmo a ser preso em 1721, pouco tempo depois de deixar a direçâo da Ordem. A sua fortuna

\footnotetext{
${ }^{38}$ A. M. C. Eleiçōes Militares. I. 1626-1707, fl. 145-145v e fl. 184-184v.
} 
ficou muito depauperada, vendo-se mesmo na contingência de pedir dinheiro emprestado sob penhores, e perdeu muita da consideração social de que gozava, tudo se agravando com o já reportado pleito judicial que manteve com a família Correia de Lacerda.

Estes três vereadores não se assemelham apenas nas suas trajetórias oficiais, já que as suas vidas privadas mostram pontos de contacto. Quando eram solteiros, todos tiveram filhos naturais de mulheres da cidade.

Manuel do Vale, consorciado em 1711 com D. Maria de Santa Rosa Caetana e Costa, senhora natural da Batalha e filha do Dr. Manuel Antunes da Costa, teve nos finais do século Xvir casa montada, na rua das Azeiteiras, a uma mulher solteira, de quem teve vários filhos. Um desses filhos, Helena Gomes do Vale, casou-se em 1713 com José Rodrigues Pinheiro ${ }^{39}$, um barbeiro que vem a ser sangrador dos cárceres da Inquisiçáo e a alcançar a familiatura, tendo sido também mester da mesa.

Manuel Bacelar tem, dois anos antes de se casar, uma filha ilegítima, de nome Bernarda ${ }^{40}$. A mãe era uma mulher chamada Maria Rodrigues, ama em casa de António de Távora Souto Maior, escrivão proprietário da Provedoria.

Manuel Mendes Trovão, casado em 1714, tem também uma filha natural, D. Mariana Micaela de Sousa Trovão, registada como filha de mãe incógnita (que era, de facto, Ana Maria de Jesus). Esta filha irá casar-se com Luís da Silva Rocha, meirinho da cidade. Em 1769, ela e o marido pediram ao Cabido a renovaçáo do prazo de uma casa situada ao pé do arco do Trováo, junto ao Largo da Sé, de que o seu pai fora enfiteuta, mas o Cabido não acedeu ao pedido (Loureiro 1960: 278). Em 1785, encontrava-se em estado de pobreza pois pediu à Misericórdia algum vestuário (mantilha, roupinhas, saia e sapatos), frisando, no entanto, que, embora necessitada, era pessoa "bem criada" (Lopes 2000: II, 236).

Estes factos, assim como os que citei a propósito do fidalgo Filipe de Sampaio e Melo, que náo podiam deixar de ser conhecidos, mostram que para

\footnotetext{
39 Casamento em 11 de junho de 1713 (A. U. C. Livro de casamentos. Coimbra, S. Bartolomeu).

${ }^{40}$ Batizada em 27 de fevereiro de 1706 (A. U. C. Livro de batismos. Coimbra, Santiago).
} 
a eleição dos ministros era muito mais determinante a condição social e os meios de fortuna do que os "bons e louváveis costumes" que a Ordem exigia para a entrada dos irmáos. E, com certeza, a exemplo do que se passava em outras instituiçôes, a Ordem seria bem mais dura na avaliação da conduta dos pobres que pediam ajuda, pobres que, para a merecerem, se tinham de sujeitar a um grande controlo nas suas vidas ${ }^{41}$.

Em suma, são os ministros escolhidos entre pessoas socialmente qualificadas, com peso na cidade, com evidente capacidade económica ${ }^{42}$, que exerceram cargos na Câmara, na Universidade, na Diocese, na Misericórdia, na Inquisição. Boa parte deles, os lentes juristas, desenvolveram carreiras na administraçáo central, em tribunais superiores, no Desembargo do Paço, na Fazenda, outros empenharam-se no oficialato local ou regional, procurando os lugares que asseguravam poder, notabilidade e boa remuneração. É pois uma associação com uma cúpula fortemente elitizada onde não há espaço, à imagem do município e da Santa Casa, para gente que se dedica à atividade comercial e ao mundo dos negócios ${ }^{43}$, e muito menos ainda para o universo mesteiral. Para a Ordem, importava ter no comando uma pessoa de prestígio e merecimento, que a representasse condignamente nas cerimónias públicas e lhe granjeasse o respeito e a consideração necessárias à sua afirmação e florescimento.

A integração nos órgãos diretivos das Ordens Terceiras proporcionava um espaço para o exercício do poder, senão material, pelo menos simbólico e, para muitos, um veículo mais de ascensão social. Mas a pertença a estas instituiçóes pias náo se poderá reduzir à procura do acrescentamento pessoal.

${ }^{41}$ O título da obra de Maria Antónia Lopes — Pobreza, assistência e controlo social — é quanto a este aspeto bem significativo.

${ }^{42} \mathrm{Na}$ Ordem Terceira de Vila Viçosa, os ministros, ao tomarem posse do cargo, tinham de contribuir com 48 mil réis para a Ordem (Araújo 2004: 53), quantia importante que restringiria o acesso aos mais abonados. Na Ordem Terceira de Coimbra, tal norma não aparece em estatutos, mas terá estado em uso uma contribuição para as despesas, de modo que chegou a ser considerada obrigação inerente aos cargos de direção (Barrico 1895: 25).

43 Diferentemente do que acontece na Galiza (Ferrol e A Graña), onde os comerciantes enriquecidos, em busca de prestígio social, têm um peso considerável (Martín García 2003: 335-339). 
Seria ditada também por um impulso espiritual e pela vontade de ser útil aos irmãos. Acima de tudo, fazia parte de um percurso de salvação, concorrendo para o resgate das culpas e abrindo caminho para a bem-aventurança eterna.

Por outro lado, a visibilidade que na sociedade barroca era facultada pelas manifestaçôes exteriores de devoção, como as missas, as novenas, as ladainhas e, sobretudo, as procissōes (no caso da Ordem Terceira principalmente a do Enterro e a de Cinza ${ }^{44}$ ), com todo o aparato cénico e a majestade do cortejo, onde os irmãos deviam estar presentes com o seu hábito, sublinhava uma distinção que engrandecia os seus ministros aos olhos de todos.

\section{BIBLIOGRAFIA:}

Arquivo Municipal de Coimbra (A. M. C.). Eleiçôes Militares. I. 1626-1707.

Arquivo Municipal de Coimbra (A. M. C.). Eleiçôes Militares. III. 1771-1794.

Arquivo da Universidade de Coimbra (A. U. C.). Cabido e Mitra da Sé de Coimbra. Capelas, cx. VII, 9 e 11.

Arquivo da Universidade de Coimbra (A. U. C.). Cabido e Mitra da Sé de Coimbra. Tombo das casas da cidade, 1745.

Arquivo da Universidade de Coimbra (A. U. C.). Cabido e Mitra da Sé de Coimbra. Visitações. Livro da devassa das freguesias da cidade de Coimbra de 1763.

Arquivo da Universidade de Coimbra (A. U. C.). Livros Notariais. Coimbra. Tabeliáo António Lopes da Cruz Freire.

Arquivo da Universidade de Coimbra (A. U. C.). Livros Notariais. Coimbra. Tabelião Pantaleão Cordeiro.

Arquivo da Universidade de Coimbra (A. U. C.). Livros Paroquiais das freguesias da cidade de Coimbra.

Arquivo da Venerável Ordem Terceira da Penitência de S. Francisco de Coimbra (A. V. O. T.). Estatutos da Ordem, [s. d.].

${ }_{44}$ Descritas por Joaquim Simóes Barrico (Barrico 1995: 93-104). Um estudo pormenorizado da procissão de Cinza, na cidade do Porto, em Ferreira-Alves 2012b: 421-472. Referências às procissões do Enterro e de Cinza, na Figueira da Foz, em período mais tardio, em Cascão 1998: 465-468. 


\section{GUILHERMINA MOTA}

Arquivo da Venerável Ordem Terceira da Penitência de S. Francisco de Coimbra (A. V. O. T.). Livro dos Estatutos da Veneravel Ordem Terceira da Penitencia de S. Francisco da cidade de Coimbra, 1659-1739.

Almeida, Fortunato de (1968). História da Igreja em Portugal. Vol II. Porto: Livraria Civilização. Almeida, Fortunato de (1970). História da Igreja em Portugal. Vol. III. Porto: Livraria Civilização. Araújo, António de Sousa (2001). "Ordens Terceiras", Carlos Moreira Azevedo, dir., Dicionário de História Religiosa de Portugal. Lisboa: Centro de Estudos de História Religiosa da Universidade Católica Portuguesa, Círculo de Leitores, III, 348-355.

Araújo, Maria Marta Lobo de (2004). "Vestidos de cinzento. Os irmãos terceiros franciscanos de Vila Viçosa, através dos Estatutos de 1686”, Revista de Cultura Callipole, 12, 47-60.

Barrico, Joaquim Simóes (1895). Noticia historica da Veneravel Ordem Terceira da Penitencia de S. Francisco da cidade de Coimbra e do seu hospital e asylo. Coimbra: Typographia de J. J. Reis Leitão.

Cascão, Rui de Ascensão Ferreira (1998). Figueira da Foz e Buarcos entre 1861 e 1910. Permanência e mudança em duas comunidades do litoral. Figueira da Foz: Centro de Estudos do Mar e das Navegaçôes; Câmara Municipal da Figueira da Foz; Livraria Minerva.

Correia, Vergílio, António Nogueira Gonçalves (1947). Inventário Artístico de Portugal. Distrito de Coimbra. Lisboa: Academia das Belas Artes.

Eiras, José Aníbal Guimarães da Costa (1980). "A obra assistêncial dos terceiros franciscanos portuenses. Elementos para o seu estudo", in Actas do Colóquio "O Porto na Época Moderna", Revista de História, 3, 21-35.

Elias, Luís Filipe da Cruz Quaresma (2010). "A Santa Casa da Misericórdia de Coimbra e o empréstimo de dinheiro a juros (1753-1765)", Revista de História da Sociedade e da Cultura, 10, I, 261-283.

Ferreira-Alves, Natália Marinho, coord., (2012a). Os Franciscanos no Mundo Português II. As Veneráveis Ordens Terceiras de Sáo Francisco. Porto: CEPESE - Centro de Estudos da Populaçáo, Economia e Sociedade.

Ferreira-Alves, Natália Marinho (2012b). "A Procissão de Cinza e a Ordem Terceira de São Francisco do Porto. Análise de um esquema devocional”, in Natália Marinho Ferreira-Alves, coord., Os Franciscanos no Mundo Português II. As Veneráveis Ordens Terceiras de São Francisco, Porto: CEPESE - Centro de Estudos da População, Economia e Sociedade, 421-472.

Fonseca, Fernando Taveira da (1995a). "As contas do Cabido da Sé de Coimbra (1760-1775). Notas de investigação", Revista Portuguesa de História, 30, 113-136. 
Varia. Os Ministros da Ordem Terceira de S. Francisco de Coimbra no século XVIII

Fonseca, Fernando Taveira da (1995b). A Universidade de Coimbra (1700-1771). Estudo social e económico. Coimbra: Por Ordem da Universidade.

Lopes, Maria Antónia (2000). Pobreza, assistência e controlo social em Coimbra (1750-1850). 2 vols. Viseu: Palimage.

Lopes, Maria Antónia (2002/2003). "Provedores e escrivães da Misericórdia de Coimbra de 1700 a 1910. Elites e fontes de poder”, Revista Portuguesa de História, 36, 2, 203-274.

Loureiro, José Pinto (1960). Toponímia de Coimbra. Vol. I. Coimbra: Edição da Câmara Municipal. Macedo, Jorge Borges de (1951). A situação económica no tempo de Pombal. Alguns aspectos. Porto: Livraria Portugália.

Machado, Diogo Barbosa (1965). Bibliotheca lusitana. Historica, critica, e cronologica na qual se comprehende a noticia dos authores portuguezes, e das obras, que compuseraó desde o tempo da promulgaçaó da Ley da Graça até o tempo prezente. Edição revista por Manuel Lopes de Almeida. Tomo I. Coimbra: Atlântida Editora.

Machado, Diogo Barbosa (1967). Bibliotheca lusitana. Historica, critica, e cronologica na qual se comprehende a noticia dos authores portuguezes, e das obras, que compuseraó desde o tempo da promulgaçaó da Ley da Graça até o tempo prezente. Edição revista por Manuel Lopes de Almeida. Tomo IV. Coimbra: Atlântida Editora.

Marçal, Maria Paula (2010). "Nobilitados entre cristãos-novos e familiares do Santo Ofício. O exemplo das casas da Família Real", Revista de Inquisición (Intolerancia y Derechos Humanos), 14, 107-135.

Martín García, Alfredo (2003). "El movimiento seglar franciscano en el noroeste gallego durante el antiguo régimen. Las V. O. T. de Ferrol y A Graña”, SEMATA, Ciencias Sociais y Humanidades, 15, 317-339.

Moraes, Juliana de Mello (2010a). “As práticas assistenciais entre os irmãos seculares franciscanos nas duas margens do Atlântico (século XVIII)”, in Ferreira, Fátima Moura, Araújo, Maria Marta Lobo de, Esteves, Alexandra, orgs., Pobreza e assistência no espaço ibérico (séculos XVI-XX). Porto: CITCEM, 185-196.

Moraes, Juliana de Mello (2010b). Viver em penitência. Os irmáos terceiros franciscanos e as suas associaçóes, Braga e S. Paulo (1672-1822). Dissertação de doutoramento. Braga: Universidade do Minho.

Mota, Guilhermina (2009). A Igreja, a Mulher e o Casamento no século XVIII. Sep. Marques, Maria Alegria Fernandes, coord., Mulher. Espírito e Norma: Actas do IV Encontro Cultural de S. Cristóvão de Laföes. S. Cristóvão de Lafôes, 103-118. 


\section{GUILHERMINA MOTA}

Mota, Guilhermina (2013). Longos e penosos meses de noivado. Um processo de esponsais na Coimbra do século XVIII. Sep. Revista Portuguesa de História, 44, 359-388.

Ribeiro, Ana Isabel do Sacramento Sampaio (2012). Nobrezas e governança. Identidades e perfis sociais (Coimbra, 1777-1820). Dissertação de doutoramento. Coimbra: Faculdade de Letras da Universidade de Coimbra.

Rodrigues, Manuel Augusto, dir. (1992). Memoria professorum Universitatis Conimbrigensis $1772-$ 1937. Coimbra: Arquivo da Universidade de Coimbra, II.

Rodrigues, Manuel Augusto, dir. (2003). Memoria professorum Universitatis Conimbrigensis 12901772. Coimbra: Arquivo da Universidade de Coimbra, I.

Sá, Isabel dos Guimarães e (2000). "Assistência. Época Moderna e Contemporânea”, in Carlos Moreira Azevedo, dir. Dicionário de História Religiosa de Portugal. Lisboa: Centro de Estudos de História Religiosa da Universidade Católica Portuguesa; Círculo de Leitores, I, 140-149.

Silva, A. Carneiro da (1991). O catálogo dos provedores e escrivães da Misericórdia. Coimbra: Santa Casa da Misericórdia de Coimbra.

Silva, Ana Margarida Dias da (2013). Inventário do Arquivo da Venerável Ordem Terceira da Penitência de S. Francisco da Cidade de Coimbra (1659-2008). Centro de Estudos de História Religiosa da Universidade Católica Portuguesa; Venerável Ordem Terceira da Penitência de S. Francisco, http://hdl.handle.net/10400.14/10334 (consultado em 30/9/2014).

Silva, Ana Margarida Dias da (2014). O Hospital e Asilo da Venerável Ordem Terceira da Penitência de S. Francisco de Coimbra (1851-1926). Dissertação de mestrado. Coimbra: Faculdade de Letras da Universidade de Coimbra.

Silva, Hugo Ribeiro da (2011). "Os cabidos catedralícios portugueses em tempos de mudança (1564-1670)”, Lusitania Sacra, 23, 77-94.

Soares, Sérgio Cunha (1991). "Os vereadores da Universidade na Câmara de Coimbra (1640-1777)”, Revista Portuguesa de História, 26, 45-80.

Soares, Sérgio Cunha (2001). O município de Coimbra da Restauração ao Pombalismo. Poder e poderosos na Idade Moderna. Coimbra: Centro de História da Sociedade e da Cultura. I. Geografia do poder municipal.

Soares, Sérgio Cunha (2002). O município de Coimbra da Restauração ao Pombalismo. Poder e poderosos na Idade Moderna. Coimbra: Centro de História da Sociedade e da Cultura. II. Sociologia do poder municipal. 


\section{MINISTROS DA ORDEM TERCEIRA}

DE S. FRANCISCO DE COIMBRA NO SÉCULO XVIII

\begin{tabular}{|c|c|c|}
\hline Ano & Nome & Caraterização social \\
\hline 1701 & Bento Antunes da Costa & prior \\
\hline 1702 & João de Sá Pereira & fidalgo \\
\hline 1703 & Bernardo Correia de Lacerda & fidalgo \\
\hline 1704 & José de Melo & cónego \\
\hline 1705 & Mateus Vieira & prior \\
\hline 1706 & Gonçalo Pereira da Silva & - \\
\hline 1707 & Diogo Ribeiro Santiago & advogado \\
\hline 1708 & Francisco Correia da Silva & - \\
\hline 1709 & Duarte de Melo e Sousa & fidalgo \\
\hline 1710 & Bernardo Correia de Lacerda & fidalgo \\
\hline 1711 & João de Sá Pereira & fidalgo \\
\hline 1712 & Manuel do Vale Souto Maior & vereador \\
\hline 1713 & António Luís de Melo e Sousa & fidalgo \\
\hline 1714 & Manuel de Abreu Bacelar & vereador; médico \\
\hline 1715 & Manuel de Almeida & jurista \\
\hline 1716 & Bernardo Correia de Lacerda & fidalgo \\
\hline 1717 & João de Sá Pereira & fidalgo \\
\hline 1718 & António de Sá Romeu & nobre; vereador \\
\hline 1719 & Manuel Mendes de Sousa Trovão & vereador \\
\hline 1720 & António Fernandes Velho & meio cónego \\
\hline 1721 & “ & “ \\
\hline 1722 & “ & “ \\
\hline 1723 & Manuel de Sá Pereira & fidalgo \\
\hline 1724 & João de Sá Pereira & fidalgo \\
\hline 1725 & “ & “ \\
\hline 1726 & João da Costa Leitão & lente; cónego \\
\hline 1727 & António de Andrade Rego & fidalgo; lente; cónego \\
\hline 1728 & Manuel Nobre Pereira & lente; cónego \\
\hline 1729 & João Francisco Leitão de Sousa & fidalgo \\
\hline 1730 & António da Cruz Ferreira & lente; chantre \\
\hline 1731 & Manuel de Matos & lente; cónego \\
\hline
\end{tabular}




\begin{tabular}{|c|c|c|}
\hline 1732 & " & " \\
\hline 1733 & " & “ \\
\hline 1734 & “ & “ \\
\hline 1735 & “ & “ \\
\hline 1736 & “ & “ \\
\hline 1737 & António Vigier & cónego \\
\hline 1738 & Miguel de Souto Maior & cónego \\
\hline 1739 & “ & “ \\
\hline 1740 & “ & “ \\
\hline 1741 & “ & “ \\
\hline 1742 & “ & “ \\
\hline 1743 & “ & “ \\
\hline 1744 & “ & “ \\
\hline 1745 & “ & “ \\
\hline 1746 & “ & “ \\
\hline 1747 & “ & “ \\
\hline 1748 & “ & “ \\
\hline 1749 & “ & “ \\
\hline 1750 & “ & “ \\
\hline 1751 & “ & “ \\
\hline 1752 & Lucas de Seabra e Silva & lente; (fidalgo) \\
\hline 1753 & António Pessoa Sá Figueiredo e Cunha & fidalgo; cónego \\
\hline 1754 & “ & " \\
\hline 1755 & “ & “ \\
\hline 1756 & António Xavier Zuzarte Maldonado & fidalgo \\
\hline 1757 & Francisco de Morais e Brito da Serra & fidalgo \\
\hline 1758 & “ & “ \\
\hline 1759 & “ & “ \\
\hline 1760 & “ & “ \\
\hline 1761 & “ & “ \\
\hline 1762 & António Bernardo de Almeida & lente; cónego \\
\hline 1763 & “ & " \\
\hline 1764 & “ & “ \\
\hline 1765 & “ & “ \\
\hline 1766 & “ & “ \\
\hline
\end{tabular}




\begin{tabular}{|c|c|c|}
\hline 1767 & "“ & "“ \\
\hline 1768 & “ & “ \\
\hline 1769 & " & “ \\
\hline 1770 & “ & “ \\
\hline 1771 & Teotónio Valério de Figueiredo & arcediago \\
\hline 1772 & “ & " \\
\hline 1773 & Francisco Lopes Teixeira & lente; médico \\
\hline 1774 & Teotónio Valério de Figueiredo & arcediago \\
\hline 1775 & “ & “ - \\
\hline 1776 & Domingos Monteiro de Albergaria & cónego \\
\hline 1777 & Teotónio Valério de Figueiredo & arcediago \\
\hline 1778 & Filipe João Saraiva de Sampaio e Melo & fidalgo \\
\hline 1779 & " & “ \\
\hline 1780 & " & “ \\
\hline 1781 & “ & “" \\
\hline 1782 & João Vieira de Melo e Sampaio* & fidalgo; cónego \\
\hline 1783 & " & “ \\
\hline 1784 & Francisco Duarte da Fonseca Montanha & lente; cónego; (fidalgo) \\
\hline 1785 & Luís António Lopes Pires & lente; cónego \\
\hline 1786 & Bento Álvares & advogado \\
\hline 1787 & " & " \\
\hline 1788 & “ & “ \\
\hline 1789 & João Vieira de Melo e Sampaio & fidalgo; cónego \\
\hline 1790 & “ & “ \\
\hline 1791 & “ & “ \\
\hline 1792 & “" & “ \\
\hline 1793 & “ & “ \\
\hline 1794 & " & “ \\
\hline 1795 & “ & “ \\
\hline 1796 & “ & “ \\
\hline 1797 & António Xavier de Brito e Castro & fidalgo; deão \\
\hline 1798 & “ & “" \\
\hline 1799 & "“ & "“ \\
\hline 1800 & Francisco Xavier de Almeida Pais & cónego \\
\hline
\end{tabular}

*Filipe de Sampaio e Melo faleceu em 6 de julho de 1782 e foi ministro até essa data. 


